\title{
CAPACITY BUILDING FOR VIRTUAL INNOVATIVE TEACHING AND LEARNING IN JORDAN - EXPERIENCES OF THE JOVITAL PROJECT
}

\author{
Katherine Wimpenny, Arinola Adefila, Alun DeWinter, Coventry University, United Kingdom, \\ Valerij Dermol, University of Ljubljana, Slovenia
}

\section{Introduction}

In a world that is increasingly interconnected, interdependent and diverse, engaging in international and intercultural learning and exchange is a key focus for higher education (HE) (Krutky, 2008; Altbach, Reisberg, \& Rumbley, 2009). This trend can be considered in relation to several issues. For example, universities are experiencing an increase in their recruitment of international students (Beech, 2018; Borjesson, 2017; Fliegler, 2014); online international learning is increasingly becoming a core pillar of university collaborations for globally networked learning (Villar-Onrubia \& Rajpal, 2016; Redden, 2014; Bell, 2016); and open courses such as Massive Open Online Courses (MOOCs) target learners, regardless of their geographic and cultural background (Maringe \& Sing, 2014; Brahimi \& Sarirete, 2015; Affouneh, Wimpenny, Ra'Fat Ghodieh, et al., 2018).

In countries like Jordan that, due to their demographic and socioeconomic context, are experiencing a massification phenomenon with respect to learners accessing higher education $(\mathrm{HE})$, responsive, effective education processes are required to maintain quality learning experiences (Affouneh \& Amin Awad Raba, 2017; Foley \& Massingila, 2014; Dian-Fu \& Yeh, 2012).

This paper presents the activities and the findings of ongoing the JOVITAL project in its goal of building the capacity of Jordanian educational technologies.

JOVITAL is an international cooperation project co-funded by the Erasmus+ Capacity Building in HE programmes of the European Union during the period October 2017 - 2020 involving four European institutions and five Jordanian universities. The aim of JOVITAL is to foster academic exchange using virtual mobility in order to offer learning opportunities to academic staff, university students and disadvantaged learners in Jordan.

\section{State-of-the-art technologies and the evolution of delivery within Higher Education}

There is a growing emphasis on using state-of -art technical infrastructure and design to captivate learners. More applications are being designed exclusively for learning and new technologies are adapted for e-learning relatively quickly in the modern age. Many institutions now view e-learning as a strategic tool which can be used to boost their reach, 
reputation and finances and there is increased competition to deliver e-learning programmes across the world, which has many implications for HEIs who do not engage. Students can attend many programmes without leaving their country, and this is beneficial for vulnerable and disadvantaged groups who have little access to HE (Affouneh et al., 2018). Nonetheless, there needs to be strategic recognition by governments in regions where there is no strategic oversight over quality, language, development and learner satisfaction for quality provision of online learning. JOVITAL explores the world-wide state of the art in terms of education technologies and this paper outlines how new and emerging technologies are being innovatively used in institutions around the world and how they are being adapted and implemented for use in Jordan. This includes applications of technology for domestic online learning, as well as worldwide partnerships that develop intercultural competences though the use of Online International Learning (OIL).

\section{Challenges in HE and Jordan}

Implementing E-learning can be a significant challenge for HE institutions at this paper explores the wider challenges of online learning, particularly, those institutions that have not explored interactive learning pedagogies or engaged in distance learning or other practices which involve engaging students outside the didactic models of classroom teaching. Elearning is dynamic and constantly evolving as new technologies and social processes become available; this means institutions have to be agile, modifying their systems and infrastructure, upskilling the workforce and adequately preparing their staff and their learners (Serdyukov, 2015). This of course can be expensive and requires strong internet connectivity. Institutions are also forced to 'keep up' with current trends and technologies, which may not be practical or affordable.

The paper also examines some of the specific and unique challenges for the region. In Jordan, e-learning has been associated with removing barriers for female learners in remote locations and providing opportunities to upskill the existing workforce (Al-Rashdan 2009). However, the challenges of ensuring high quality training is offered has been discussed by employers leading to restrictions; at present, for example, Jordanian undergraduate degrees cannot contain more cannot contain more than $25 \%$ of its total content on online learning.

This limit can also be seen as a rejection of E-learning methodologies as an inferior or lazy option where learning content is simply dumped online with little effort to contextualise the learning or to improve the learner experience. A key challenge is therefore a change in mindset from using technology not as a tool, but as platform for education, something which requires a change of mindsets away from the "teacher at the front" model of learning and a shift in approach to course design and pedagogical implementation.

This paper explores another unique challenge for Jordan; equity of access and inclusion of Syrian refugees in the region. Although Jordanian institutions wish to include refugees in elearning, a number of barriers exist. In 2017, the Open University attempted to deliver online courses to Syrian Refugees in Jordan, which was not well received due to the lack of 
interactivity (Bothwell, 2017). This paper explores attitudes towards e-learning within the different learner communities and how the JOVITAL project has come to address them.

\section{Gains and benefits to student experience and changes to pedagogy}

One of the most important benefits of e-learning is the choice it affords to students to study at a convenient "pace, place and mode" in order to ensure that the quality of teaching and learning is maintained (Serdyukov, 2015; p.15). This paper argues that the mode of delivery can enhance or inhibit this affordance and properly designed e-learning programmes allow for learner-centred flexible approaches to HE education. As such, a key area for consideration is the role of the academic / facilitator, and their skills and competencies in e-learning, which the next section moves on to discuss.

Buhl, Andreasen, and Pushpanadham (2018) suggests e-learning fragments lecturers' traditional roles. They are no longer the sage responsible for "planning, practice and reflection", rather, such activities may now be "performed by different actors with different areas of responsibility" (p.180) Many institutions have had to introduce support for the technical and design areas of delivering e-learning -and roles have emerged in terms of learning technologists, e-developers, etc. (Veletsiano, 2011).

In addition, lecturers have to adopt new skills and techniques so they can prepare and engage their learners to become reflexive learners in e-learning environments. This is challenging because though modern learners are accustomed to the technology, they are not necessary adept as engaging in transformative learning and lack the kind of digital capital that enables them to be co-creators of their own learning (Warner \& Palmer, 2015; Sadeghi, 2018). The JOVITAL project has made training an integral part of the delivery, with methods and approaches to teacher training being discussed as part of the paper.

Institutions have the responsibility to ensure that staff are adequately equipped to perform their role, and equally learners need to be supported to study online, with the necessary skills of autonomy and self-efficacy. The preparation of learners is a considerable task, not least because pre- university education does not typically prepare learners with these skills. Elearning also requires that learners have communicative and networking tactics to engage in such online learning spaces.

Furthermore, institutions need to concern themselves with ensuring that assessment practices are suitable for e-leaning. Assessment needs to align with the evolution of e-learning. Students of the $21^{\text {st }}$ century need to develop requisite skills (problem-solving, team work and communication skills) for the workplace (Warner \& Palmer, 2015). As such, assessments should be varied and flexible.

\section{Final thoughts}

Through presenting and exploring the activities and findings of JOVITAL, this paper seeks to outline the challenges and benefits of e-learning technologies in Higher Education teaching 


\section{Capacity Building for Virtual Innovative Teaching and Learning in Jordan - Experiences of the JOVITAL Project \\ Katherine Wimpenny et al.}

and learning, and how these can be tailored for use within the unique Jordanian context. This paper argues that online learning, in many forms, is of benefit to students and teachers alike, but utilisation of technologies requires careful planning, tailoring and training in order to see maximum benefit. As such, it is imperative that time is taken to train teaching staff and to prepare student expectations of online learning in order to gain the maximum benefit elearning technologies have to offer. It is not simply enough to buy into technology and expect it do all of the work - changes to approach and implementation are vital to the success of online approaches to pedagogy.

\section{References}

Affouneh, S. J., \& Amin Awad Raba, A. (2017). An Emerging Model of E-Learning in Palestine: The Case of An-Najah National University. Creative Education, 8, 189-201.

Affouneh, S., Wimpenny. K., Ra'fat Ghodieh, A., Abu Alsaud, L., \& Abu Obaid, A. (2018). Reflection on MOOC Design in Palestine: A MOOC as a tool for nationality building. The International Review of Research in Open and Distributed Learning, 19(2), 23-36. Retrieved from http://www.irrodl.org/index.php/irrodl/article/view/3469/4610

Al-Rashdan, A.-F. A. (2009). Higher Education in The Arab World: Hopes and Challenges. In M. Elmenshawy (Ed.), New Chapter of Political Islam. Arab Insight (Vol. 2, pp. 77-90). ISSN 1936-8984.

Altbach, P. G., Reisberg, L., \& Rumbley. L.E. (2009). Trends in Global Higher Education: Tracking an Academic Revolution. UNESCO.

Beech, S. (2018). Adapting to change in the higher education system: international student mobility as a migration industry. Journal of Ethnic and Migration Studies, 44(4), 610-625.

Bell, S. (2016). Sustainable distance learning for a sustainable world. Open Learning, 31(1), $1-8$.

Borjesson, M. (2017). The global space of international students in 2010. Journal of Ethnic and Migration Studies, 43(8), 1256-1275.

Bothwell, E. (2017). Online higher education 'unappealing' for Syrian refugees. Times Higher Education [Blog post]. Retrieved from https://www.timeshighereducation.com/news/online-higher-education-unappealingsyrian-refugees\#survey-answer

Brahimi, T., \& Sarirete, A. (2015). Learning Outside the classroom through MOOCS. Computers in Human Behaviour, 51, 604-609.

Buhl, M., Andreasen, L. B., \& Pushpanadham, K. (2018). Upscaling the number of learners, fragmenting the role of teachers: How do massive open online courses (MOOCs) form new conditions for learning design? International Review of Education, 64(2), 179-195.

Dian-Fu, C., \& Yeh, C. C. (2012). Teaching Quality after the Massification of Higher Education in Taiwan. Chinese Education and Society, 45(5/6), 31-44. 
Fleigler, C. M. (2014). Recruiting the World. University Business, 17(10), 36-41.

Foley, A., \& Masingila, J. (2014). Building capacity: challenges and opportunities in large classes pedagogy in Sub-Saharan Africa. Higher Education, 67(6), 797-808.

Krutky, J. (2008). Intercultural competency: Preparing students to be global citizens. Effective Practices for Academic Leaders, 3(1), 1-15.

Maringe, F., \& Sing, N. (2014). Teaching large classes in an increasingly internationalizing higher education environment: pedagogical, quality and equity issues. Higher Education, 67(6), 761-782.

Redden, E. (2014, July 9). Teaching with Tech across Borders. Inside Higher Ed [Blog post]. Retrieved 12 May, 2015, from https://www.insidehighered.com/news/2014/07/09/facultyuse-internet-based-technologies-create-global-learning-opportunities

Sadeghi, S. H. (2018). E-Learning Practice in Higher Education: A Mixed-Method Comparative Analysis.

Serdyukov, P. (2015). Does Online Education Need a Special Pedagogy? Journal of Computing and Information Technology - CIT, 23(1), 61-74. doi:10.2498/cit.1002511 61

Veletsianos, G. (2011). Designing Opportunities for Transformation with Emerging Technologies. Educational Technology, 51(2), 41-46. Retrieved from https://www.jstor.org/stable/44429917

Villar-Onrubia, D., \& Rajpal, B. (2016). Online International Learning: Internationalising the Curriculum through Virtual Mobility at Coventry University' Perspectives. Policy and Practice in Higher Education, 20(2-3), 75-82.

Warner, T., \& Palmer, E. (2015). Personalising learning: Exploring student and teacher perceptions about flexible learning and assessment in a flipped university course. Computers \& Education, 88, 354-369 